\title{
The Effects of Some Prebiotic Products (Actigen, Biotronic Top3) Administrated in the Food of Broiler Chickens on the Meat Quality
}

\author{
Aurel ŞARA ${ }^{1 *}$, Radu MARȚI ${ }^{2}$, Mihai- Iacob BENȚEA ${ }^{1}$, Ionel TOADER ${ }^{1}$, Erol- Florian GABOR ${ }^{3}$ \\ ${ }^{1}$ University of Agricultural Sciences and Veterinary Medicine Cluj-Napoca, Romania \\ ${ }^{2}$ Biomin, Romania \\ ${ }^{3}$ Momaja Expert SRL \\ * corresponding author: aurel.sara@usamvcluj.ro
}

Bulletin UASVM Animal Science and Biotechnologies 73(2)/ 2016

Print ISSN 1843-5262; Electronic ISSN 1843-536X

DOI:10.15835/buasvmcn-asb: 12239

\begin{abstract}
Following the $2006 \mathrm{EU}$ ban of antibiotic-based growth promoters, the use of alternative products, such as prebiotics, became a necessity. The goal of this study was to determine the effects of prebiotic products (Actigen and Biotronic Top3) on meat quality in broiler chickens. The research has been conducted on a number of 75 Ross308 hybrid broilers, assigned in three groups ( 25 individuals/group), over a period of 42 days. Group 1(E) was fed with the base diet supplemented with the Actigen prebiotic in a proportion of $0.08 \%$ in the first growth phase (days $1-14$ ), $0.04 \%$ in the second phase (days $14-35$ ) and $0.02 \%$ in the third phase (days 35-42). Group 2(E) received the base feed supplemented with the Biotronic Top3 prebiotic $(0.1 \%)$ throughout the whole growth period. At the end of the study period, five broilers from every group have been sacrificed to determine meat quality and meat chemical composition. The usage of prebiotics led to an increase of the carcass weight gain of $16.29 \%$ in group 1(E) receiving Actigen and $13.49 \%$ in group 2(E), fed with Biotronic Top3, compared to the control group. The percentage of superior quality meat (quality I and II) in the carcass was higher by $4.4 \%$ in group 2(E) Biotronic Top3 and by $1.67 \%$ in group 1(E) Actigen compared to the control group. Following the administration of Actigen and Biotronic Top3 prebiotics, in groups 1(E) and 2(E) the meat quality was improved in groups 1(E) and 2(E), due to an increase in the protein content and a reduction of the fat content. These results confirm that prebiotics administered in the feeds for broiler chickens have favourable effects on the meat production and meat quality.
\end{abstract}

Keywords: Actigen, Biotronic Top3, broiler chicken, meat composition, meat quality

\section{INTRODUCTION}

After the EU ban of the antibiotic-based growth promoters in 2006, the focus shifted towards other alternative products, such as prebiotics.

Multiple researches worldwide reported that the use of the Actigen prebiotic in broiler chicken nutrition, led to better results regarding body weight, feed conversion index, health status and slaughter yield, when compared to their respective control groups (Bozkurt et al. 2009; Corneille, 2011; Culver et al. 2011; Gernat, 2011; Kill, 2010; Lausten et al. 2011; Lea et al. 2011; Munyaka et al. 2011; Olejniczak et al. 2011; Sasou, 2011; Venkatesh, 2010, Yang et al. 2008;).

The Biotronic Top3 prebiotic is a synergistic combination of organic acids and their salts, phytochemical products and the Biomin $®$ PerforizerTM permeabilization agent, playing an active role in increasing feed digestibility and inhibiting bacterial proliferation by reducing the $\mathrm{pH}$ levels in the gastro-intestinal tract (Biomin, 2016).

The aim of this study was to determine the effects of these two prebiotic products (Actigen 
and Biotronic Top3) on meat quality of broiler chicken.

\section{MATERIALS AND METHODS}

The research has been carried out in a private poultry farm (PFA Ciotea Marius, Cluj-Napoca, Cluj County, over a period of 42 days (December 2015 - January 2016). Seventy-five broiler chickens (Ross-308 hybrid) have been randomly allocated to the three study groups, each group consisting of 25 birds.

The control group was fed with the base diet, group $1 \mathrm{E}$ was fed with the base diet supplemented with Actigen $0.08 \%$ in the first growth phase (114 days), $0.04 \%$ in the second phase (14-35 days) and $0.02 \%$ in the third phase (35-42 days). Group $2 \mathrm{E}$ was fed with the base die supplemented with Biotronic Top3 at a steady rate of $0.1 \%$ throughout the whole experimental period. The feeds administered to the three groups were balanced and had similar energy and protein levels.

At the end of the experimental period 5 birds from each group were sacrificed. The slaughter yield and the commercial yield were determined along with the meat quality and crude chemical composition of meat. To assess the meat quality, were determined for each individual, the carcass weight and the weight of individual parts (head, neck, breast, leg, leg + thigh, back and wings). Meat samples were collected from the thighs and breast regions for meat composition analysis. Dry matter, crude protein, crude fat and crude ash content were determined.

The results were recorded and analysed using the GraphPad InStat ver. 3.10 software, by means of the Student test.

\section{RESULTS AND DISCUSSION}

The mean values and the variability of the slaughter yield are shown in Tab. 1.
Differences have been recorded when comparing the values for the slaughter yield (Tab. 1) recorded for the three groups. The mean value of the slaughter yield was $74.26 \%$ for the control group, $75.96 \%$ for the Actigen group (1E) and75.39\% for the Biotronic Top3 group (2E). The highest yield was recorded in the Actigen group, $2.29 \%$ higher than the yield recorded in the control group, followed by the Biotronic group, with a yield $2.10 \%$ higher than the control group, the recorded slaughter yields of the experimental groups being almost equal. Similar results being reported by Bozkurt et al. 2009, Culver et al. (2011), Lausten et al. (2011).

The commercial yield values had a similar trend as the slaughter yield values. The highest value was recorded in the Actigen group (1E) with a average value of $80.13 \%$, followed by the Biotronic group (2E) with a average value of $79.80 \%$, the lowest commercial yield being recorded in the control group, with a value of only $78.82 \%$. The highest economic efficiency was recorded in the Actigen group, followed by the other two groups. When expressed in relative values, the commercial yield was $1.66 \%$ higher in the Actigen group compared to the control group and $0.42 \%$ higher compared to the Biotronic group. The relative value of the commercial yield was $1.24 \%$ higher compared to the control group (Tab. 2). Similar results regarding the slaughter yield of broiler chickens were reported by Bozkurt et al. (2009) and Culver et al. (2011).

The results presented in Tab. 3 show that the percentage of higher quality meat in the carcass $\left(1^{\text {st }}\right.$ and $2^{\text {nd }}$ quality) was higher in the Actigen group (87.34\%) compared to the control group, who totalled $86.69 \%$. The Biotronic group also showed and increased percentage of higher quality meat (1st and 2nd quality) in the carcass $(87.25 \%)$ compared to the control group. Similar increases of higher quality meat in the carcass

Tab. 1. Mean values and variability of the slaughter yield in broiler chickens

\begin{tabular}{|c|c|c|c|}
\hline \multirow{3}{*}{ Group } & \multicolumn{3}{|c|}{ Yield } \\
\hline & \multicolumn{2}{|c|}{ Absolute } & \multirow{2}{*}{$\begin{array}{c}\text { Relative } \\
\% \\
\end{array}$} \\
\hline & $X \pm S x$ & $\mathrm{~V} \%$ & \\
\hline Control Group (n=5) & $74.26 \pm 0.47$ & 1.41 & 100.00 \\
\hline Group 1(E) ACTIGEN $(n=5)$ & $75.96 \pm 0.52$ & 1.53 & 102.29 \\
\hline Group 2(E) BIOTRONIC $(n=5)$ & $75.82 \pm 0.57$ & 1.69 & 102.10 \\
\hline
\end{tabular}


were also reported by Bozkurt et al. (2009), Lea et al. (2011).

The results regarding the crude chemical composition of broiler chicken meat (breast and thigh) are presented in Tab. 4 and Tab. 5.

The values presented in Tab. 4 show a superior increase in crude protein content in the Actigen group (1E) compared to the control group, the recorded values being $21.93 \%$ in the Actigen group and $21.73 \%$ in the control group.

The two prebiotics also had a positive influence on the crude fat content, the lowest value being recorded in the Biotronic group (2.71\%), when compared to the control group (3.14\%).

The chemical composition of meat from the thigh (Tab. 5) had the same characteristics as the ones recorded in the breast meat, the only difference being recorded for the crude protein content, the highest values being recorded in the Biotronic group (18.69\%) and in the Actigen group (18.55\%), when compared to the control group (18.13\%). The crude fat content had the same, the lowest values being recorded in the Biotronic group (9.27\%) followed by the Actigen

Tab. 2. Mean values and variability of the commercial yield in broiler chickens

\begin{tabular}{|c|c|c|c|c|}
\hline \multirow{3}{*}{ Group } & \multicolumn{4}{|c|}{ Yield } \\
\hline & \multicolumn{3}{|c|}{ Absolute } & Relative \\
\hline & $\mathrm{n}$ & $X \pm S x$ & $\mathrm{~V} \%$ & $\%$ \\
\hline Control Group & 5 & $78.82 \pm 0.46$ & 1.32 & 100.00 \\
\hline Group 1(E) ACTIGEN & 5 & $80.13 \pm 0.56$ & 1.56 & 101.66 \\
\hline Group 2(E) BIOTRONIC & 5 & $79.80 \pm 0.51$ & 1.42 & 101.24 \\
\hline
\end{tabular}

Tab. 3. Carcass quality based on the weight of individual parts of broiler chicken

\begin{tabular}{|c|c|c|c|c|c|c|}
\hline \multicolumn{7}{|c|}{ Meat quality (\% of carcass) } \\
\hline \multirow[t]{2}{*}{ Group } & \multicolumn{2}{|c|}{$\begin{array}{c}1^{\text {st }} \text { Quality } \\
\text { (breast + thigh + leg) }\end{array}$} & \multicolumn{2}{|c|}{$\begin{array}{l}2^{\text {nd }} \text { Quality } \\
\text { (back. wing) }\end{array}$} & \multicolumn{2}{|c|}{$\begin{array}{c}3^{\text {rd }} \text { Quality } \\
\text { (head. neck. thighs) }\end{array}$} \\
\hline & absolute & Relative & Absolute & Relative & Absolute & Relative \\
\hline Control Group & 60.12 & 100.00 & 26.57 & 100.00 & 13.31 & 100.00 \\
\hline $\begin{array}{l}\text { Group } 1(\mathrm{E}) \\
\text { ACTIGEN }\end{array}$ & 60.49 & 100.62 & 26.85 & 101.05 & 12.66 & 95.12 \\
\hline $\begin{array}{l}\text { Group } 2 \text { (E) } \\
\text { BIOTRONIC }\end{array}$ & 59.03 & 98.19 & 28.22 & 106.21 & 12.75 & 95.79 \\
\hline
\end{tabular}

Tab.4. Crude chemical composition of broiler chicken meat (breast)

\begin{tabular}{ccccc}
\hline Issue & Dry matter (\%) & Crude Protein (\%) & Crude Fat (\%) & Crude Ash (\%) \\
\hline Control Group & $25.74 \pm 0.57$ & $21.73 \pm 030$ & $3.14 \pm 0.16$ & $1.16 \pm 0.04$ \\
\hline Group 1E (Actigen) & $26.63 \pm 0.46$ & $21.93 \pm 0.17$ & $3.10 \pm 0.20$ & $1.21 \pm 0.04$ \\
\hline Group 2E (Biotronic Top3) & $25.04 \pm 0.41$ & $21.56 \pm 0.25$ & $2.71 \pm 0.14$ & $1.15 \pm 0.03$ \\
\hline p $>0.05 \%$ - non-significant differences & & &
\end{tabular}

Tab.5. Crude chemical composition of broiler chicken meat (thigh + leg)

\begin{tabular}{ccccc}
\hline Issue & Dry matter (\%) & Crude Protein (\%) & Crude Fat (\%) & Crude Ash (\%) \\
\hline Control Group & $29.21 \pm 1.25$ & $18.13 \pm 0.32$ & $10.28 \pm 0.50$ & $0.96 \pm 0.01$ \\
\hline Group 1E (Actigen) & $28.71 \pm 1.02$ & $18.55 \pm 0.19$ & $9.79 \pm 0.20$ & $0.94 \pm 0.04$ \\
\hline Group 2E (Biotronic Top3) & $28.11 \pm 0.69$ & $18.69 \pm 0.31$ & $9.27 \pm 0.38$ & $0.97 \pm 0.02$ \\
\hline $\mathrm{p}>0.05 \%$ - non-significant differences & & & &
\end{tabular}


group (9.79\%) and by the control group (10.28\%). The highest values for the crude ash content of the breast meat were recorded in the Actigen group, while in the thigh meat, the highest value was recorded in the Biotronic group, followed by the control group and the Actigen group. These data show an improvement of the meat quality as a result of the increase in protein content and the decrease of the fat content in the Actigen and Biotronic fed groups; comparable results have also been reported by Bozkurt et al. (2009), Culver et al. (2011) or Lausten et al. (2011).

\section{CONCLUSION}

The use of these prebiotics (Actigen and Biotronic Top3) in the feeds for broiler chicken determined the improvement of the slaughter yield by $2.29 \%$ for the Actigen group and $2.10 \%$ for the Biotronic group, compared to the control group.

Actigen and Biotronic administered to broiler chickens increased the content of superior quality meat $\left(1^{\text {st }}\right.$ and $2^{\text {nd }}$ quality) in the carcass $(87.34 \%$ - Actigen, 87.25\% - Biotronic) compared to the control group (86.69\%).

The results recorded for the crude chemical composition show an improvement of the meat quality by increasing the protein content and decreasing the fat content in the experimental groups.

These results confirm the positive effects of these prebiotic products (Actigen and Biotronic Top3) on production and meat quality in broiler chickens.

\section{REFERENCES}

1. Biomin (2016) - Aditivi furajeri şi Specialități- Catalog Actigen Top3 Growth promoter/ Antibacterian.

2. Bozkurt M, Kucukyilmaz K, Catli AU, Cinar M (2009). Effect of dietary mannan oligosaccharide with or without oregano essential oil and hop extract supplementation on the performance and slaughter characteristics of male broilers. S. Afr. J. Anim. Sci., 39: 223-232.
3. Corneille S (2011). Effect of feeding Actigen on broiler's performance. Alltech Summary Report, Japan, pp: 6.

4. Culver J, Nollet L (2011). Actigen ${ }^{\mathrm{TM}}$ impact on broiler growth and production economics. "Science and Techolology in the Feed Industry Conference". Proceedings of Alltech's 27th Annual International Symposium Lexington, Kentucky, USA.

5. Gernat A (2011). Actigen ${ }^{\mathrm{TM}}$ and Zn bacitracin: Comparative effects on performance, intestinal integrity and immunity of broilers. "Science and Techolology in the Feed Industry” Conference. Proceedings of Alltech's 27th Annual International Symposium Lexington, Kentucky, USA.

6. Kill JL, Haese D, Del Puppo D, Borsoi RB, E. Das Graca Lacerda, Oliveira de ES (2010). Product Evaluation: Actigen $^{\mathrm{TM}}$. Centro de Technoligia Animal (CTA), Brazil, pp: 12.

7. Lausten P, Nollett L, Moran C, (2011). Use of Actigen in a high performing Danish broiler flock. Alltech Summary Reports, pp: 1-10.

8. Lea HK, Burton EJ (2011). Performance and gut health of poultry in the post-antibiotic era when feeding a novel yeast cell wall component. "Science and Technology in the Feed Industry" Conference. Proceedings of Alltech's 27th Annual International Symposium Lexington, Kentucky, USA.

9. Munyaka P., Echeverry HM, Yitbarek A, Einarson M and Sharif S, Guenter W, House JD, Rodriguez- Lecompte JC (2011). Toll-like receptors and cytokines profile of chickens supple-mented with yeast-derivate carbohydrates. Proceedings of the Alltech's 27th International Animal Health and Nutrition Industry Symposium, May 22-25, 2011, Lexington, KY., USA.

10. Olejniczak Renata, Nollet L (2011). Evaluation of the effectiveness of Actigen ${ }^{\mathrm{TM}}$ as a growth promoter in broilers. "Science and Technology in the Feed Industry" Conference. Proceedings of Alltech's 27th Annual International Symposium Lexington, Kentucky, USA.

11. Sasou E., Corneille S (2011). Effect of feeding actigen on growth performance and mortality. Alltech Summary Report, Japan, pp: 6.

12. Venkatesh (2010). Control vs. Actigen: iSolutions evaluation. Andaman Islands, India, Alltech Summary Report, pp: 5.

13. Yang Y., Iji PA, Kocher A, Mikkelsen LL, Choct M (2008). Effects of dietary mannanoligosaccharide on growth performance, nutrient digestibility and gut development of broilers given different cereal-based diets. J. Anim. Physiol. Anim. Nutr., 92: 650-659. 